\title{
Luz, sombra, penumbra e a criação de sentidos em A erva do rato
}

\author{
Susana Madeira Dobal' \\ https://orcid.org/0000-0003-3730-6604 \\ Ana Carolina Roure Malta de Sál \\ https://orcid.org/0000-0003-0756-2455 \\ I - UNB \\ Brasília (DF), Brasil
}

Resumo: O artigo propõe uma reflexão acerca da importância do trabalho de direção de fotografia de Walter Carvalho na construção da luz, da sombra e da penumbra, como recursos que trazem camadas de sentido para a narrativa de $A$ erva do rato, de Júlio Bressane. O filme é uma livre adaptação cinematográfica dos contos "Um esqueleto" e "A causa secreta", ambos de Machado de Assis, e narra a história de uma estranha parceria amorosa, abalada pelo surgimento inusitado de um rato. Elementos como voyerismo, perversão e fetichismo transparecem à meia-luz ou por meio do chiaroscuro, em uma atmosfera misteriosa e obscura. Luz e sombra atuam como elementos estruturantes do filme e dialogam com referências pictóricas.

Palavras-chave: direção de fotografia; luz; sombra; penumbra; chiaroscuro.

Abstract: Light, shadow, twilight and the creation of meanings in $A$ erva do rato - This paper proposes a reflection on the importance of Walter Carvalho's cinematography to transform light, shadow and darkness into resources that create layers of meaning in the narrative of Julio Bressane's A erva do rato. The film is a free adaptation of the short stories "Um esqueleto" and "A causa secreta", both by Machado de Assis, and tells the story of a strange love partnership, shaken by the unexpected appearance of a rat. Elements such as voyeurism, perversion and fetishism appear in the dim light or through chiaroscuro, in a mysterious and obscure atmosphere. Light and shadow act as structuring elements of the film and dialogue with pictorial references.

Keywords: cinematography; light; shadow; twilight; chiaroscuro.

\section{Introdução}

A erva do rato (2008), de Júlio Bressane, traz uma releitura de dois contos de Machado de Assis, "Um Esqueleto" e "A causa secreta", utilizados apenas como ponto de partida 
para a criação de uma terceira história. Na versão cinematográfica, a atenção que seria dada principalmente aos personagens pode, porém, ser deslocada para o protagonismo da luz e da sombra como elementos estruturantes da narrativa. Loiseleux (2005, p. 0708, tradução nossa) nos aponta a importância da significação de ordem psicológica, emocional, dramática e atmosférica da luz. Ele enfatiza que criar a luz no cinema "é participar do desenvolvimento da história que o realizador conta, dominando as emoções produzidas pela luz, seu efeito sensível nos corpos e nos rostos, nos cenários e objetos". Partindo desse pressuposto, este estudo propõe uma reflexão acerca da importância do trabalho de direção de fotografia de Walter Carvalho na construção da luz, da sombra e da penumbra, como recursos que trazem camadas de sentido para narrativa do filme em questão, além de estabelecer um diálogo com referências da pintura na construção dessas formalizações estéticas.

A erva do rato pode ser considerado um filme sobre pulsão escópica, sobre voyeurismo levado ao extremo, como veremos mais adiante. Na obra de Bressane, homem e mulher jamais se tocam, mas estabelecem uma intimidade singular quando ele a fotografa: em meio a sombras ambulantes, ambos atuam em papéis de voyeur e exibicionista e lidam com o prazer e a abjeção. Atmosfera obscura, sombras, duplos e o chiaroscuro guiam o espectador em um jogo de evasiva cumplicidade em torno desse casal. O tema do desejo e do gozo assume diversas configurações relacionadas à direção de fotografia, assim, expressão e conteúdo se constroem e se completam ao mesmo tempo.

As análises serão desenvolvidas a partir de três diferentes modos de emprego da luz, apontados por Aumont (2004) em O olho interminável, que ele também irá tratar como funções da luz na representação e que englobam, obviamente, a forma de seu negativo, a sombra. São elas: simbólica, dramática e atmosférica. Também levaremos em consideração dois tipos básicos de sombra, propostos por Bordwell e Thompson (2013): a sombra própria e a sombra projetada.

Para aprofundarmos nossas análises acerca da sombra e do duplo, recorremos ao estudo de Stoichita (2016), Rank (2013) e à noção do unheimlich freudiano (1919/2006), que nos traz um novo entendimento acerca dessa formalização estética. O destaque dado para a sombra no filme terá grande relevância neste artigo a fim de compreendermos de que modo as sombras próprias e projetadas podem expressar certos aspectos psíquicos dos personagens. As análises também serão desenvolvidas em interlocução com as ideias de Freud (1905) acerca dos conceitos de voyeurismo, perversão e fetichismo, bem como com as de Quinet (2004), principalmente no que se refere à noção de pulsão escópica. O recurso à psicanálise para tratar de questões estéticas relativas a esse filme mostra-se fundamental para compreender como luz e sombra atuam de maneira a enfatizar aspectos da narrativa, ou ainda de expressar o que as palavras nem sempre alcançam. 


\section{A erva do rato: uma livre adaptação e o seu enredo}

O filme conta a história da estranha relação de um casal. O espectador jamais saberá o nome dos personagens, isso será um mistério, como também será a vida pregressa de ambos. Quando passam a viver juntos, o cotidiano se resume em uma atividade na qual o homem dita informações contidas em livros, enquanto ela as anota em cadernos que se acumulam sobre a mesa. Quase não há intimidade entre eles, não há reciprocidade de olhar e há poucos diálogos. Com o tempo, ele abandona os ditados e Ihe endereça uma obscura demanda: fotografá-la. Tomada pela fantasia de fazer dele seu parceiro amoroso, a mulher se coloca diante da câmera de modo sensual. Posteriormente, ele a convence a se desnudar, entretanto, enquanto ela se oferece por inteiro ao seu olhar, o que ele captura com sua objetiva é a imagem de fragmentos de seu corpo, para depois encerrálos em uma caixa. Assim, o que os manterá unidos será, por parte dela, a necessidade de ocupar o lugar de mulher desejada; ele, por sua vez, tomará partes impressas do corpo dela como objetos de desejo perverso, revelando sua "solução" fetichista de um gozo não genital (FREUD, 1905/2006).

Mais adiante, um rato irá se interpor entre o casal, figurando como um terceiro na relação. Ele emerge das sombras, caminha pelos cômodos e se sacia com as fotos do corpo da mulher. Perplexo face às fotografias roídas, o homem é invadido pela obsessão de capturá-lo. Enquanto isso, o animal passa a se relacionar eroticamente com a mulher, estimulando sua libido e consolidando os desejos jamais consumados com seu parceiro. Por fim, o rato é mutilado na frente dela, que, petrificada pelo acontecimento, entra em colapso e morre. Ao final, o espectador se depara com o personagem, que continua a estabelecer com o corpo da mulher, agora desencarnado, uma parceria perversa. Assim, a figura de um esqueleto passa a ocupar o seu lugar na cama, na banheira, tomando chá e, também, na sua condição de objeto, já que o homem continua a fotografá-la nas mesmas poses de outrora.

Nessa livre adaptação, Bressane se apropria apenas do que acredita ser importante para a construção de uma terceira narrativa. Como afirma Xavier (2003, p. 62), "o lema deve ser 'ao cineasta o que é do cineasta, ao escritor o que é do escritor' ", princípio este que nos permite entender o fato de o realizador assumir os textos literários apenas como ponto de partida, a fim de criar uma nova experiência, agora cinematográfica. Sendo assim, do conto "Um Esqueleto", o realizador retira a ideia de um homem que passa a conviver com o esqueleto de sua falecida após assassiná-la e, do conto "A Causa Secreta", utiliza a imagem de um homem sádico, que sente enorme prazer ao mutilar um rato. De ambas as histórias, o desejo perverso do personagem masculino, a morte da esposa e a figura de uma terceira pessoa, que se interpõe de algum modo na relação do casal. O ambiente noturno e a atmosfera sombria estão presentes em ambos os contos, mas é no filme que esses aspectos obscuros e misteriosos ganham ainda mais relevância, principalmente, por meio da fotografia. 


\section{A direção de fotografia em $A$ erva do rato}

Júlio Bressane e Walter Carvalho são parceiros de longa data, trabalharam juntos em A viola chinesa (1976), Filme de amor (2003), Cleópatra (2007), Educação sentimental (2013). No catálogo da mostra A luz (Imagem) de Walter Carvalho, Bressane (2014, p. 59) tece algumas considerações sobre a parceria com o fotógrafo: "Toda colaboração é misteriosa, escreveu escritor do passado. A colaboração entre Walter e eu não foi diferente. O cinema, talvez como a pintura, pelo menos a pintura praticada à época do ateliê, é feito por muitas mãos". O cineasta eleva a condição do fotógrafo à de colaborador e, portanto, concede certa autonomia a ele para que possa desenvolver o seu trabalho como artista criador.

Para Loiseleux (2005, p. 05, tradução nossa), "a experimentação da fotografia e, acima de tudo, da cinematografia oferece um campo de jogo ideal para os curiosos que são tentados a dominar a luz como um modo de expressão". O valor expressivo alcançado pelo embate de claro-escuro nas experimentações empreendidas por Walter Carvalho remete a estratégias próprias da pintura Barroca, evidenciando com a luz uma sensualidade dos corpos, além de investir as cenas com uma carga emocional. A narrativa se desenvolve quase completamente na penumbra e a partir de contrastes como os do chiaroscuro barroco. Segundo Loiseleux (2005, p. 03, tradução nossa), a luz tem a função "de dar sentido à imagem pela maneira como ilumina o tema e pela atmosfera emocional que gera, fazendo com que seres e objetos apareçam não apenas sob seu aspecto estético mais favorável, mas também com plena coerência para cada filme".

Em $A$ erva do rato, luz, sombra e penumbra adquirem igual importância para a construção dos sentidos da narrativa. Se, por um lado, o enredo conta a história do encontro de um casal, por outro, a utilização de recursos relacionados à luz torna visível os efeitos devastadores causados pela dimensão perversa que constitui essa relação, além de atuar como fator de expressividade das cenas de alto teor dramático. A complexa articulação entre amor, desejo e gozo configura-se no trabalho de direção de fotografia de Walter Carvalho a partir da criação de sombras e duplos que deambulam entre as cenas e passam a atuar como elementos metafóricos importantes. O trabalho com a luz também é responsável por criar a penumbra, que produzirá a atmosfera obscura necessária para que o enigma da trama se desenvolva. Sombra e luz carregam conotações diversas e essas diferentes significações atribuídas a ambos os elementos serão estruturantes, pois darão sustentação e conduzirão a narrativa.

\section{Luz, sombra, penumbra e a criação de sentidos}

Em Breve história da sombra, Stoichita (2016, p. 142) traz uma das acepções dadas ao vocábulo sombra por um dos primeiros dicionários de língua francesa: "SOMBRA, toma-se por um inimigo quimérico. Combateremos ainda a nossa sombra? Ou seja, 
as nossas desconfianças e os nossos pensamentos". Para ele, "esta definição evoca, pois, uma interiorização da sombra enquanto projeção pessoal, enquanto 'zona obscura' da alma, onde a negatividade interior ganha corpo" (ibidem).

Essa reflexão nos permite pensar o "inimigo quimérico" como exteriorização da obscuridade recôndita própria ao humano, "algo que deveria ter permanecido oculto mas veio à luz" (SCHELLING apud FREUD, 1919/2006, p. 258), o que nos remete ao unheimlich freudiano materializado na forma de duplo. Este, projetado para fora, pelo ego, como algo estranho a si mesmo, na verdade, não é nada novo ou alheio, mas algo familiar há muito estabelecido na mente e que se separou desta após sofrer o processo de repressão. A ideia de estranho familiar (unheimlich) sustenta que um afeto pertencente a um impulso emocional, após ser reprimido, retorna metamorfoseado em um elemento amedrontador (FREUD, 1919/2006). O inimigo quimérico é, portanto, como podemos deduzir, o "outro eu", que se dá a ver por meio do fenômeno do duplo. Um exemplo importante a ser mencionado é a própria representação do "inimigo quimérico" como sombra nos livros de emblemas, o que não é de modo algum uma coincidência, visto que "a sombra emblematiza, por assim dizer, a reduplicação negativa" (STOICHITA, 2016, p. 142). O duplo dá a ver justamente a parte rejeitada, reprimida do sujeito, que é projetada para fora como um modo de defesa, a fim de manter a ilusão de onipotência do eu (RANK, 2013).

A primeira sequência do filme apresenta planos em que aspectos sombrios dos personagens se materializam como sombra projetada ou, como diria Stoichita (2016), como uma "reduplicação negativa". A narrativa inicia-se em um cemitério à beira-mar, onde homem e mulher se encontram pela primeira vez. A aproximação entre eles ocorre quando ela desmaia e ele a socorre. O quadro a seguir (Fig.1) denuncia as ambiguidades desse personagem: a discrepância entre o que ele de fato é e o modo como irá se mostrar para a mulher inicialmente. Desse modo, o que ele oculta e que só será revelado mais adiante na narrativa é exteriorizado pelo seu duplo já na primeira sequência do filme.
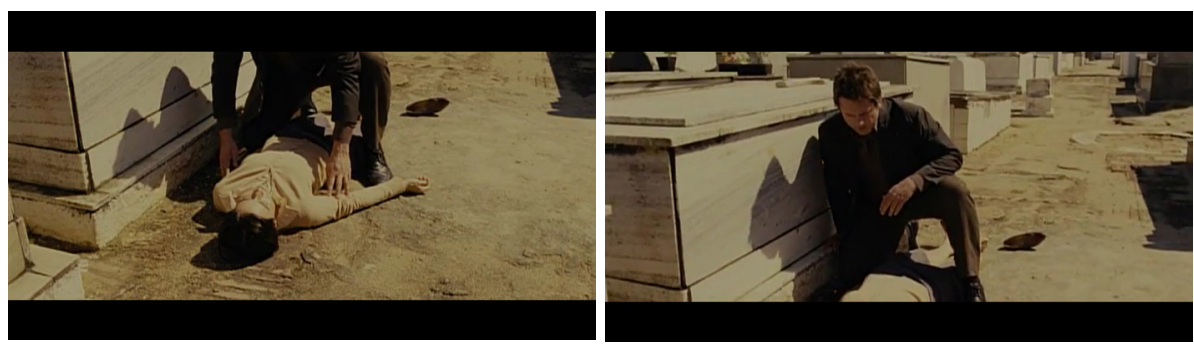

Fig. 1. Sombras, duplos e função simbólica. Fonte: A Erva do Rato (2008)

Nesse plano (Fig. 1), a sombra, investida de atributos narrativos que metaforizam a "zona obscura" da alma, exerce sua função simbólica, criando camadas de sentido para 
a narrativa. É quase como se houvesse duas cenas distintas em termos de significado: enquanto o homem ajuda a personagem a se reanimar, a sua sombra projetada no corpo da mulher, ou, também podemos dizer, o seu duplo, parece tentar possuí-la. O duplo dele é uma espécie de projeção de aspectos reprimidos de seu eu. É como se o sujeito expulsasse para fora de si seus desejos, seus impulsos e inclinações ocultas, a fim de manter a ilusão de um eu unificado, inteiro, perfeito, onipotente.

A sombra dele projetada na lápide chega a se unir à sombra dela no chão, o que metaforiza a união dos duplos de ambos. Nessa cena, assim como em várias outras, a sombra atua como instrumento ativo de significação capaz de revelar ao espectador o estranho que os constitui. Temos aqui o unheimlich de Freud (1919/2006) materializado na forma dos duplos, e que dá a ver também o caráter de singular estranheza próprio à relação mortífera que se estabelecerá entre ambos. Por isso, além de comparecer como um "inimigo quimérico", ou, também podemos dizer, como o "outro eu", o duplo manifesta um outro aspecto ressaltado por Freud (1919/2006, p. 252), o de "estranho anunciador da morte". Aspecto esse que ganha ainda mais relevância por se tratar de um duplo projetado em uma lápide e no chão de um cemitério.

No quadro abaixo (Fig. 2), o homem está atrás de sua câmera, pronto para capturar a primeira imagem da mulher, o que, inicialmente, parece ser apenas um despretensioso registro, já que a condição fetichista do protagonista ainda não terá sido revelada. $\mathrm{Na}$ verdade, até esse instante, tanto os personagens quanto o tipo de relação que será estabelecida entre eles são da ordem do mistério. Por isso, essa imagem pode ser entendida como um prenúncio visual em que luz e sombra antecipam aspectos cruciais da trama por meio de seu uso simbólico. Jullier e Marie (2009, p. 38) enfatizam a importância da luz para dar sustentação a uma narrativa: "a própria direção da luz pode apoiar a história [...]. Além da direção na qual ela cai, a própria quantidade de luz que cai sobre o sujeito pode enriquecer um retrato psicológico".

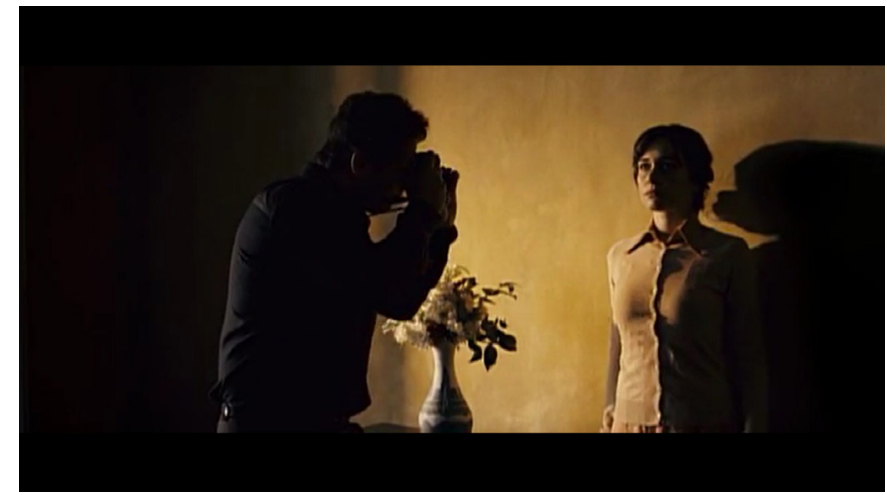

Fig. 2. Cena construída a partir de um chiaroscuro com profusão de sombras.

Fonte: A Erva do Rato (2008) 
O quadro pertence a um plano fixo, que enfatiza o chiaroscuro. Caravaggio e Rembrandt se reconfiguram nessa imagem, principalmente, no que diz respeito ao tratamento da luz. Do primeiro, percebemos as características apontadas por Argan (2013, p. 249): "a paisagem desaparece das composições caravaggianas, as sombras tornam-se quase negras e se contrapõem, sem transições, a luzes violentas"; do segundo, a predominância de uma monocromia dourada aliada a um trabalho de contraste entre luz e sombra, como podemos ver em Autorretrato com 23 anos (1629), São Pedro na prisão (1631), O filósofo em meditação (1632), Os peregrinos de emaús (1648). De ambos, vemos o uso de uma luz lateral, que ilumina uma maior porção do lado direito do quadro, enquanto o esquerdo permanece quase completamente na obscuridade. A sombra parece emergir do interior de cada um dos personagens para obscurecer o corpo, a face de cada um e termina por transbordar para o ambiente externo que os envolve.

No caso dela, a sombra se manifesta de dois modos: em contraposição à luz, conferindo um efeito de contraste que a divide em dois lados, um claro e um escuro; e como um duplo negativo projetado na parede. Ambas as formas de substancialização da sombra - sombra própria e sombra projetada - atuam na construção dessa personagem. O embate chiaroescuro produzido em seu corpo antecipa seus conflitos face ao homem com quem acredita estabelecer uma parceria amorosa. Os sentimentos dela são ambíguos em relação a ele, pois, apesar de se submeter às suas demandas, não há reciprocidade no jogo de sedução estabelecido por ela. Não há um olhar reconhecedor, cujo investimento libidinal é constitutivo de toda relação amorosa (ZALCBERG, 2007). Quanto ao seu imenso duplo, ele dá a ver os sentimentos de angústia que a constituem e que se ampliarão face à condição de objeto que ela será convocada a assumir nessa estranha parceria.

No caso do homem, a sombra invade quase completamente toda a superfície da parede do lado em que ele se encontra e estende-se por toda a sua face e corpo, reduzindo-o a uma mera silhueta, metaforizando o próprio universo interior do personagem, obscurecido por sua condição psíquica. Como veremos com o desenrolar da narrativa, existe uma defasagem entre eles, pois a fantasia perversa que o possui é diferente da fantasia dela, que busca sustentar um elo amoroso. Assim, a parceria, que de início se estabelece, está fundada em um grande equívoco. Esse descompasso será evidenciado imageticamente em alguns momentos do filme, como ocorre, por exemplo, no último plano da sequência a seguir.

O plano (Fig. 3) se inicia com a seguinte fala do personagem ao comentar sobre o gigante da Guanabara: "O gigante tem dois semblantes. Dois (pausa). Duas caras. Duas (pausa)". Enquanto ele dita para ela essas palavras, parece reconhecer um eco de identificação com o gigante. Tal como o gigante da Guanabara, ele possui duas caras: de um lado, o homem protetor com saber enciclopédico, de outro, um homem cujas fantasias estão por se revelar. 

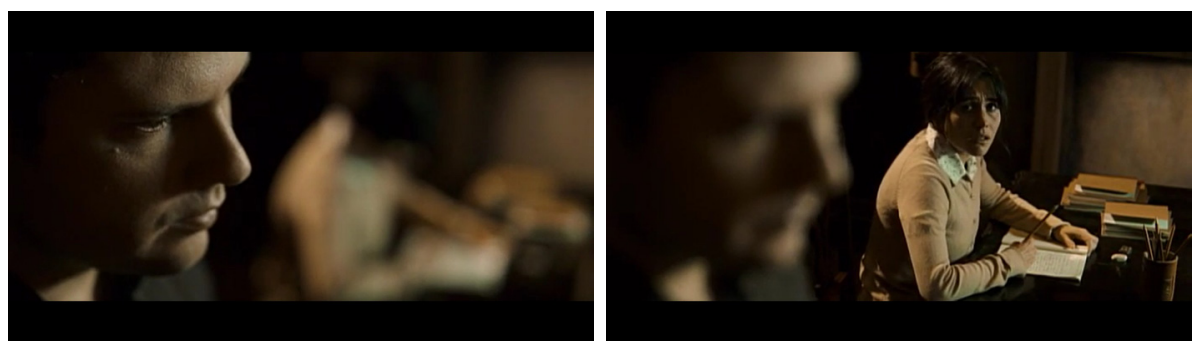

Fig. 3. Sombras deformadoras e flou artístico conferem à cena uma significação de ordem psicológica. Fonte: A Erva do Rato (2008)

O enquadramento em primeiro plano e a iluminação contrastada, aliada ao uso do flou artístico (AUMONT, 2006), sempre deixando um dos dois reduzido à indefinição, produzem uma forte atmosfera emocional. Quando o rosto dele aparece focado, vemos seu olhar sem elo com a presença desfocada dela; é como se ele não a enxergasse, e isso é sugerido ao espectador na própria imagem, já que temos a impressão de a cabeça dela ter sido tragada pela escuridão. Quando o foco sai do rosto dele e focaliza o rosto dela, vemos o semblante angustiado da mulher, uma vez que ele - agora desfocado - não se deixa ver por completo. A angústia dela dá a ver a não reciprocidade de um investimento libidinal de natureza escópica entre eles; não há cruzamento de olhares, não há fascínio especular por parte dele. No filme, para a personagem, a ausência desse olhar, que promoveria a libidinização do seu corpo e a faria única, desperta sentimentos de angústia e desamparo. Luz e sombra, no rosto dos personagens, exacerbam sua expressão, seja de indiferença para um, seja de súplica para o outro, intervindo também como um fator de dramatização.

\section{O voyeur}

A erva do rato pode ser considerado um filme sobre pulsão escópica e voyeurismo por dois motivos principais: a temática da narrativa e o modo como ela se configura, convocando também o espectador a uma condição de voyeur. Quanto à temática, trata-se de um filme que fala sobre a libido de ver e sobre a satisfação sexual por meio do olhar, a partir da história de um fotógrafo/voyeur, que nega à mulher um olhar que a seduza e se satisfaz ao fotografar apenas suas partes íntimas para objetificá-las em imagem estática. A partir de uma perspectiva psicanalítica, pensamos o olhar como objeto da pulsão escópica e os modos de satisfação dessa pulsão: a Schaulust, o gozo do olhar (QUINET, 2004).

Na sequência abaixo (Fig. 4), o ato de fotografar é encenado para situar homem e mulher em seus papéis de voyeur e exibicionista. Veremos que expressão e conteúdo se articulam a fim de dar visibilidade a três elementos fundamentais: a pulsão escópica, o voyeurismo e o fetichismo. Antes de iniciarmos a análise, retomemos uma reflexão de Quinet (2004, p. 129) sobre o conceito de pulsão escópica: "permitiu à psicanálise 
reestabelecer uma função de atividade para o olho não mais como fonte da visão, mas como fonte de libido. [...] Lá onde estava a visão, Freud descobre a pulsão". O trecho ajuda a pensar a libido de ver ou o prazer da satisfação escópica, bem como seus desdobramentos na narrativa.
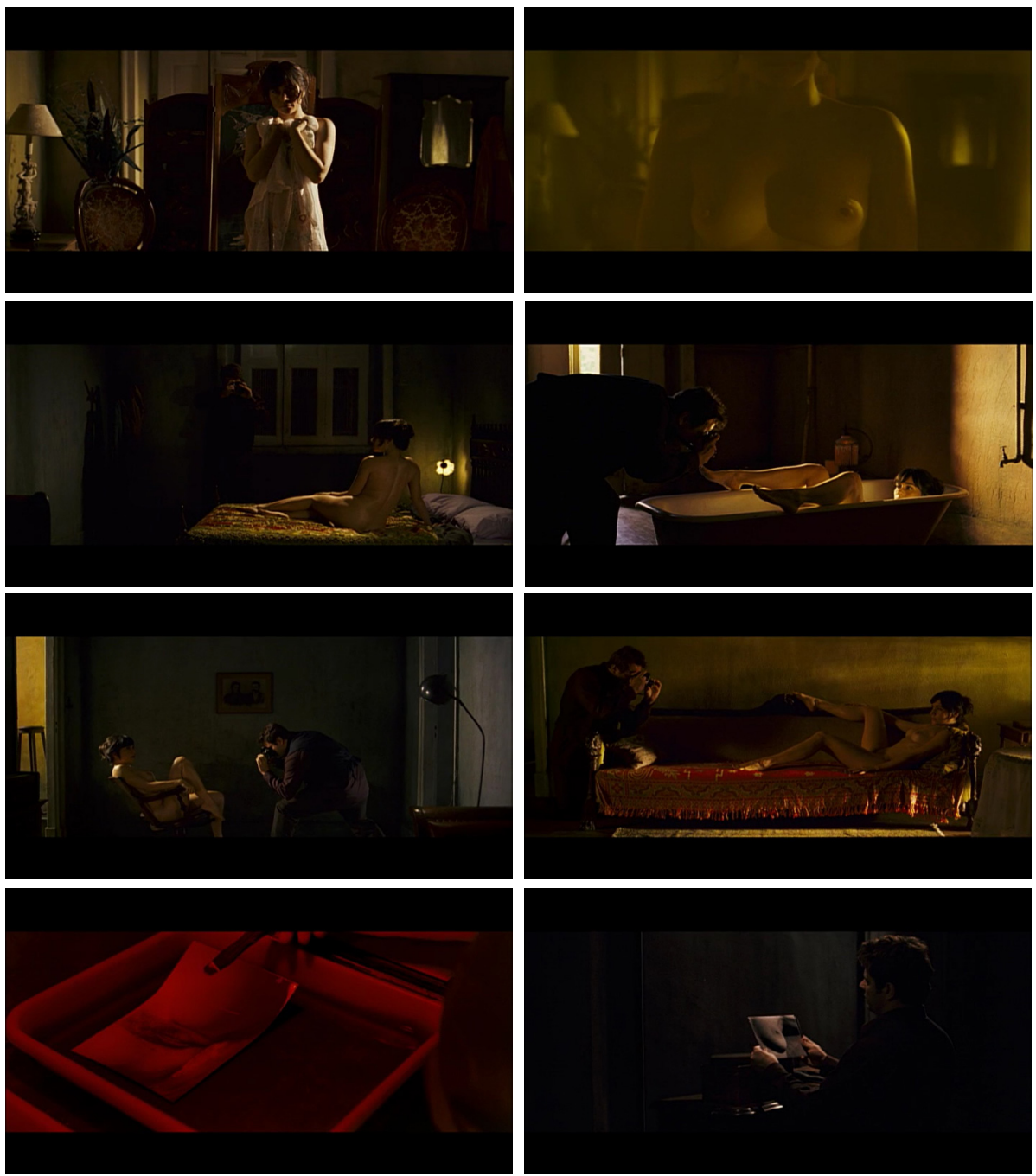

Fig. 4. O fotógrafo produz com a câmera os seus objetos fetiches.

Fonte: A Erva do Rato (2008)

A sequência ocorre na penumbra, é composta por planos fixos frontais, mais longos, com poucos cortes e com movimentação mínima dentro do quadro. O primeiro plano 
é construído a partir de uma câmera subjetiva que empresta ao espectador o olhar do fotógrafo-voyeur mediado por uma objetiva. Ele a enquadra em um plano americano, enquanto ela, seminua, após alguns segundos estática, se aproxima olhando fixamente em seus olhos. Ao parar na frente dele, ela se despe por completo, retirando o lenço que ocultava suas partes íntimas para colocá-lo diante da câmera. Nesse momento, a luz se torna mais dourada, a imagem mais opaca e o que podemos ver é um plano detalhe que enquadra os seios da mulher ao mesmo tempo que "decepa" parte de sua cabeça para fora do quadro; o restante de sua face e o tronco serão obscurecidos pela sombra. Esse plano subjetivo não só convida o espectador a enxergar pelos olhos da câmera do fotógrafovoyeur, mas também antecipa imageticamente o que continuará sendo enquadrado por ele em suas próximas fotografias.

Nos planos subsequentes, o homem continua a fotografá-la, porém a percepção visual do fotógrafo será retirada do espectador, que passará a observar a cena em terceira pessoa. O plano subjetivo e com enquadramento mais fechado dará lugar a um plano objetivo e mais aberto, permitindo que ambos, voyeur e exibicionista, ocupem o mesmo espaço cênico. A câmera, agora, passa a proporcionar ao espectador um ponto de vista imparcial e privilegiado de testemunha da cena. Os planos prolongados permitem que os olhos do espectador tenham tempo suficiente para notar informações importantes como, por exemplo, que não há jogo de olhares entre o homem e a mulher. Ela olha para ele sem ser correspondida - o que justifica a falta do uso do recurso campo-contracampo que reforçaria a reciprocidade do olhar entre os personagens e também a direção para onde o fotógrafo aponta a sua câmera: sempre para as partes íntimas do corpo dela. Por fim, os dois últimos planos mostram o resultado das imagens registradas pelo voyeur e o que se vê são apenas fragmentos íntimos de um corpo feminino. No penúltimo, nos deparamos com um papel fotográfico branco, que aos poucos revela a imagem de uma vulva, e, no último, com o fotógrafo olhando seus objetos fetiches.

Em "Três ensaios sobre a teoria da sexualidade", Freud (1905/2006, p. 145) discorre sobre o fetichismo, enunciando a existência de situações em que "[...] o objeto sexual normal é substituído por outro que guarda certa relação com ele, mas que é totalmente impróprio para servir ao alvo sexual normal"1. Esse substituto, que recebe a denominação de fetiche, pode ser uma parte do corpo pouco apropriada para as finalidades sexuais (pés, cabelos), ou algum objeto inanimado que mantenha uma relação de referência com a pessoa que ele substitui, como uma peça íntima, um acessório. Em seguida, Freud diferencia os casos em que o objeto sexual deve assumir uma condição fetichista para que o alvo sexual, tido como normal, seja atingido, daqueles casos em que o alvo sexual é abandonado por completo em favor do objeto fetiche. Entretanto, ao mesmo tempo que afirma que é normal ao relacionamento amoroso certo grau de fetichismo "sobretudo nos

1 Para Freud, o termo alvo sexual normal se refere à união dos órgãos genitais no coito, que leva ao alívio da tensão sexual e à saciação provisória da pulsão sexual. Podemos nos referir a esse termo também como meta ou objetivo sexual normal. 
estágios de enamoramento em que o alvo sexual normal é inatingível ou sua satisfação parece impedida" (ibidem, p. 145-146), ele também adverte que a situação se torna patológica "quando o anseio pelo fetiche se fixa, indo além da condição mencionada, e se coloca no lugar do alvo sexual normal, e ainda, quando o fetiche se desprende de determinada pessoa e se torna o único objeto sexual" (ibidem, p.146). Em outras palavras, se um certo grau de fetichismo é elemento constitutivo de qualquer relação amorosa, será a fixação ou superestimação do objeto fetiche como substituto do objetivo sexual que fará desse mecanismo um caso exemplar de perversão.

Sontag (2004), em seu ensaio sobre a fotografia, traz uma reflexão acerca do aspecto perverso de tirar fotos. Para ela, "se os fotógrafos profissionais têm, muitas vezes, fantasias sexuais quando estão atrás da câmera, talvez a perversão resida no fato de que essas fantasias sejam, ao mesmo tempo, plausíveis e muito impróprias" (ibidem, p. 23). Isso porque usar uma câmera fotográfica não é um meio próprio de se relacionar sexualmente com alguém, já que há, inevitavelmente, uma distância entre o fotógrafo e seu objeto. Afinal,

a câmera não estupra, nem mesmo possui, embora possa atrever-se, intrometer-se, atravessar, distorcer, explorar e, no extremo da metáfora, assassinar — todas essas atividades que, diferentemente do sexo propriamente dito, podem ser levadas a efeito à distância e com certa indiferença (ibidem, p.23).

No filme, o homem toma o aparato fotográfico justamente para realizar as suas fantasias mais perversas, fazendo uso da objetiva, que funciona como uma espécie de prótese ocular, para fragmentar o corpo da mulher a fim de se apropriar desses fragmentos (vulva, seios, nádegas) em sua versão impressa. A câmera se torna, então, a mediadora dessa não-relação entre homem e mulher, produzindo a "dessexualização" dessa parceria, ao mesmo tempo que possibilita ao personagem masculino um gozo escópico com a construção - e posteriormente com a observação e posse - de seus objetos fetiches. Assim, diferentemente da mulher, que se oferece como objeto de desejo, para com ele estabelecer certo grau de intimidade, comum em qualquer relação amorosa, ele se mantém cada vez mais distante afetiva e intimamente sem oferecer a ela um olhar que a possibilite se sustentar no lugar de mulher desejada. Concordamos com Sontag (2004): em termos metafóricos, a câmera pode assassinar. Em A erva do rato, ela recorta, fragmenta, despedaça a mulher, destruindo sua inteireza e individualidade para reduzi-la a pedaços de carne. De acordo com Cesarotto (1996, p. 119),

membros separados, cabeças decepadas, mãos desprendidas dos braços são elementos intrinsecamente sinistros, porque concretizam a quebra da unidade narcísica, desatando um terror profundo. Quando reais, a simples visão destas mutilações resulta incômoda para quem se depara com elas. 
O plano a seguir (Fig. 5) pertence à sequência anterior. Nele veremos que também a sombra própria pode fragmentar, desmembrar, decepar partes do corpo da personagem, como o voyeur faz com a câmera. Sobre um fundo vermelho, destacam-se as costas, as nádegas, parte dos braços e das panturrilhas da mulher, enquanto isso, rosto, seios, ventre, vulva, coxa são completamente engolidos pela sombra. O desmembramento trinca a unidade narcísica, afinal "qualquer que seja a mutilação, seu efeito é sempre o mesmo, pois o despedaçamento, se consumado, faria o sujeito desaparecer" (CESAROTTO, 1996, p. 150). O unheimlich surge agora materializado na mutilação do corpo humano. Diante dessa imagem, o efeito de estranheza surge, portanto, ao nos deparamos com um corpo fragmentado, acéfalo, sem identidade, sem sua inteireza, mergulhado em uma luz vermelha, como se fosse um pedaço banhado em sangue.

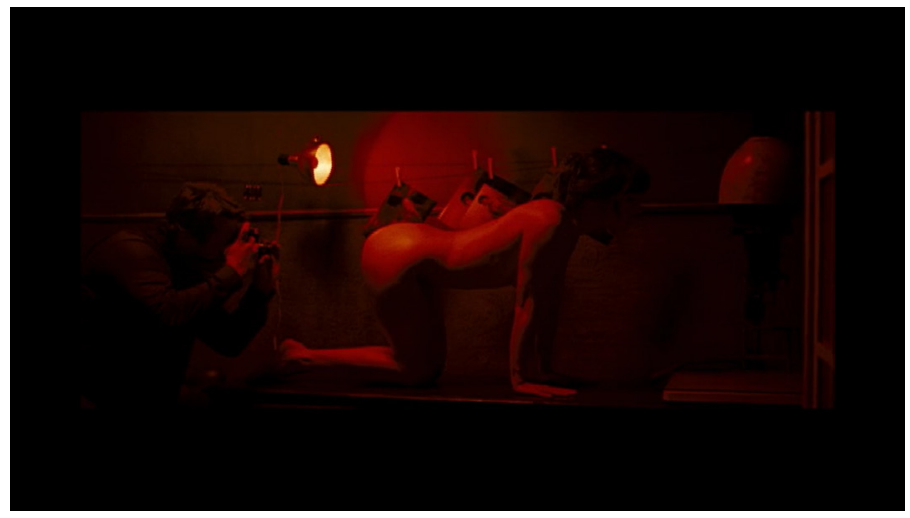

Fig. 5. Um corpo fragmentado pela sombra. Fonte: A Erva do Rato (2008)

Na sequência a seguir (Fig. 6, 7 e 8), o homem fotografa a mulher, mas dessa vez eles ganham um espectador: uma sombra de uma figura masculina de papel projetada na parede. A ideia de incluir um observador fictício - que também poderíamos entender como um voyeur - para espreitá-los é do protagonista masculino a fim de estimular a mulher, que já não se mostra mais tão entusiasmada ao posar para as fotos. No primeiro plano (Fig. 6), vemos a sombra enorme do homem e a sombra do espectador em menor dimensão, ambas projetadas na parede, sendo que a sombra do espectador é interceptada pelo homem, e só será vista em sua inteireza quando ele decidir se deslocar. Segundo Stoichita (2016, p. 138), "a distorção e amplificação da sombra [...] é uma das técnicas mais utilizadas pelas artes figurativas para sublinhar a carga negativa de um personagem". Por isso, o duplo do protagonista ganha um tamanho exacerbado, justamente para explicitar imageticamente a dimensão psíquica perversa do protagonista voyeur. Já a sombra do observador, de tamanho menor e interceptada pelo homem, nos dá a ver a condição desse terceiro, que se constitui como um elemento criado e, portanto, controlado pelo protagonista para manter o status quo dessa estranha relação. 

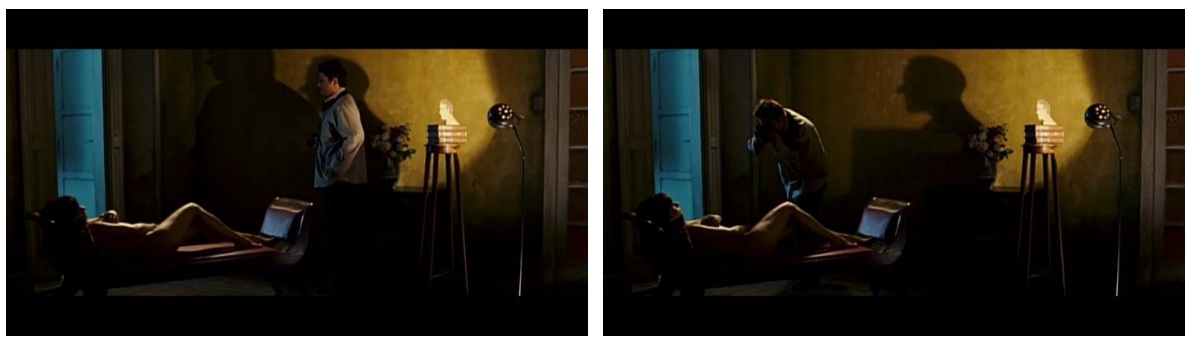

Fig. 6. O duplo do protagonista e o espectador inventado para estimular a libido da mulher.
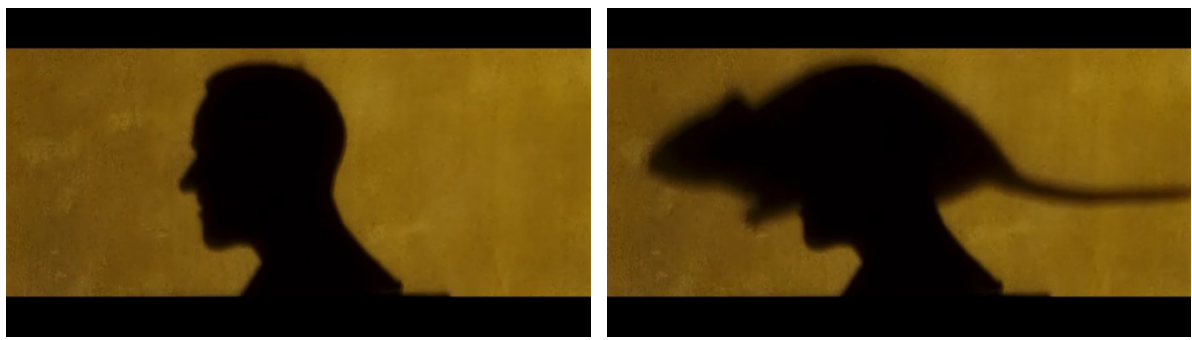

Fig. 7. Fusão de sombras: o rato se sobrepõe à figura do espectador.
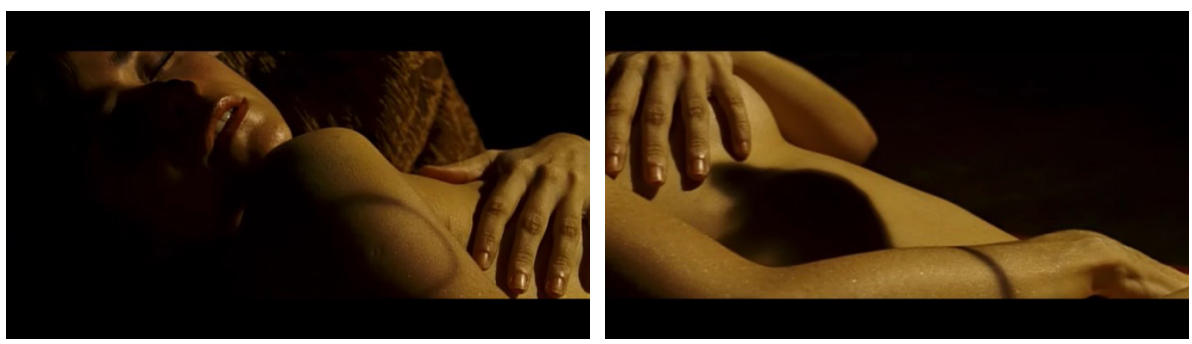

Fig. 8. Desejo e abjeção transparecem no jogo de luz e sombra.

Fonte: A Erva do Rato (2008)

No segundo plano (Fig. 7), vemos a sombra do voyeur ser superposta pela sombra do rato, o que imageticamente explicita uma mudança de direção no jogo que aí se estabelece: se o voyeur é produto das fantasias do homem que espera reavivar o desejo da mulher com um terceiro fictício, sem novamente satisfazê-la sexualmente, o rato adquire autonomia e se tornará um elemento desestabilizador, que fugirá ao controle do protagonista, manifestando-se como aquele que afetará a relação do casal. O rato será quem vai roer o fetiche do fotógrafo e o responsável por devolver à mulher o gozo de natureza sexual não oferecido a ela. Sendo assim, vemos no terceiro plano (Fig. 8), a sombra do rato ganhando vida e deambulando sobre o corpo nu da mulher, que sente prazer ao ter o seu desejo consumado. 
Por fim, como mencionado no início do tópico, o modo como a narrativa se configura imageticamente conduz o espectador do filme também a uma condição de voyeur. Além do enquadramento, a iluminação é um dos dispositivos estéticos responsáveis por tornar isso possível; primeiro, porque o uso de uma fonte artificial para iluminar áreas mais escuras dentro do quadro possibilita que o ponto iluminado solicite uma visão aproximada, colocando o espectador em uma relação de intimidade com o representado (CORRAIN, 2004); segundo, porque a penumbra cria uma atmosfera psicológica de anonimato perfeita para o voyeurismo. Aliados à iluminação, os planos fixos longos, que enquadram os personagens e seus poucos movimentos, convocam o olhar do espectador, porque lhe concedem tempo para espiar a nudez da personagem feminina e depois as fotografias dos fragmentos de seu corpo, ao mesmo tempo que o fotógrafo o faz. Mas, para além disso, esses planos possibilitam ao espectador espiar o ato de fotografar, que situa o homem e a mulher em seus papéis de voyeur e exibicionista, e o ato de olhar do homem que se excita diante do seu fetiche: as fotografias.

\section{Considerações finais}

Nessa livre adaptação dos contos de Machado de Assis, Bressane, ao mesmo tempo que se apropria de alguns elementos da fonte literária que considera importantes para a construção de sua versão cinematográfica, ressignificando-os, incorpora outros fundamentais, que não estão presentes nas narrativas originais. Afinal, os contos e o filme foram concebidos em tempos diferentes, dispondo de linguagens distintas; "escritor e cineasta não têm exatamente a mesma sensibilidade e perspectiva, sendo, portanto, de esperar que a adaptação dialogue não só com o texto de origem, mas com o seu próprio contexto" (XAVIER, 2003, p. 62). A fotografia still é um exemplo; presente apenas na narrativa fílmica, constitui-se como elemento fundamental do enredo, já que se apresenta como uma chave para explicitar o comportamento dos personagens. Outro exemplo é o rato: no conto, é um personagem secundário e, no filme, se torna um antagonista, que estimula a libido da personagem feminina e é investido de mais sentidos. Ele passa de criatura indesejável a participante de uma estranha parceria, o que é particularmente enfatizado por uma atmosfera obscura, produzida pela penumbra, por sombras e pelos efeitos de contraste chiaroscuro. O sentimento de estranheza (unheimlich) produzido por tal adaptação fílmica termina por possibilitar uma nova experiência e deve ser apreciado como obra distinta dos contos que a inspiraram.

Bressane recria e atualiza Machado de Assis a partir do uso potencializado da cinematografia e do cinema, posto também em diálogo com a pintura. Diálogo esse que comparece na construção fotográfica de $A$ erva do rato, seja na reconfiguração de estratégias estéticas próprias às obras de Rembrandt e Caravaggio para a linguagem fílmica, seja na simulação de qualidades pictóricas por meio da combinação de dispositivos 
cinematográficos que convocam o olhar do espectador para uma sensação de estar diante de uma pintura.

Na obra La luz en el cine, Loiseleux (2005) salienta a importância da luz como meio de expressão no cinema. Segundo ele, o modo como determinado objeto será iluminado irá influenciar a percepção e, consequentemente, a emoção de quem o contempla. Assim, a mesma situação sob duas luzes distintas será percebida e sentida de maneiras diferentes. Por isso, enfim, em A erva do rato a luz funciona de maneira tão expressiva: ela diminui a visibilidade das coisas concretas para conduzir a um território de sentidos múltiplos ou mais impronunciáveis. De certa forma, o rebaixamento da luz permite que se saia do território das denotações e se alcance o reino das conotações fundado, nesse caso, pela função poética da sombra e por reverberações psíquicas que a luz e a sombra vêm materializar.

O trabalho de Walter Carvalho com a luz apresenta grande relevância para criar camadas de sentido para a narrativa, o que confirma o papel fundamental da direção de fotografia ao longo do filme. Ele privilegia o que se poderia chamar de uma luz negativa, a fim de contar a história do (des)encontro de um casal, cuja relação é conduzida pela vontade de gozo do personagem masculino. O diretor de fotografia cria um jogo de luz e sombra que possibilita a manifestação das três funções da luz e da sombra na representação (simbólica, dramática e atmosférica), mencionadas por Aumont (2004). A penumbra cria uma atmosfera de intimidade ao mesmo tempo que remete a uma segunda realidade sombria; um mundo quase invisível que a pouca luz recria é, enfim, o mundo das pulsões, que conduz o estranho comportamento dos personagens plenos de (obscuro) desejo.

Em A erva do rato, a inquietante estranheza (unheimlich) das sombras termina se impondo de um modo determinante na narrativa. Como sombra própria, fragmenta rostos e corpos, enfatizando a expressividade dos atores, com o intuito de conceder à cena uma carga emocional, ao mesmo tempo que ressalta os aspectos psíquicos dos personagens. Como sombra projetada, parece conceder vida aos duplos deambulantes, que ora corporificam a face oculta de cada protagonista, ora indicam que o mundo concreto conduz também a um mundo impalpável de reflexos. Imerso na meia-luz representada, o espectador tem então uma experiência estética que lhe proporciona o prazer de acompanhar uma linguagem poética em que a luz e a sombra revelam sentidos outros.

Susana Madeira Dobal é professora no Programa de PósGraduação em Comunicação, na Universidade de Brasília (UnB). Fez mestrado em fotografia (ICP/NYU), doutorado em História da Arte (CUNY/GC) e pós doutorado na Université Paris 8 (2009) e na Aix-Marseille Université (AMU 2014). É fotógrafa.

sudobal@gmail.com 
Ana Carolina Roure Malta de Sá é doutoranda no PPG em Comunicação, na linha Imagem, Estética e Cultura Contemporânea, na Universidade de Brasília (UnB). Possui mestrado em Comunicação Social (UnB), especialização em Filosofia da Arte (IFITEG) e graduação em Letras (PUC-GO). anacarolinaroure@gmail.com

\section{Referências}

ARGAN, G. C. História da Arte italiana: de Michelangelo ao futurismo. São Paulo: Cosac \& Naify, 2003. v. 3.

ASSIS, M. de. Um Esqueleto. In. Obra Completa II. Rio de Janeiro: Nova Aguilar, 1994.

ASSIS, M. de. A causa secreta. In. Várias histórias. Rio de Janeiro: Garnier, 1994.

AUMONT, J. O olho interminável: cinema e pintura. São Paulo: Cosac \& Naify, 2004.

A Estética do Filme. São Paulo: Papirus, 2006.

BRESSANE, J. O grão da voz. In. COUTINHO, A.; GOMES, B. L.; BARBOSA, C. A luz (imagem) de Walter Carvalho. Rio de Janeiro, 2013, 219 p. Catálogo de exposição, abril, 2013, Caixa Cultural. p. 58-59.

BORDWELL, D.; THOMPSON, K. A arte do cinema: uma introdução. Campinas: Unicamp; São Paulo: Edusp, 2013.

CESAROTTO, O. No olho do outro: "O homem da areia" segundo Hoffmann, Freud e Gaiman. São Paulo: Iluminuras, 1996.

CORRAIN, L. A espacialidade no quadro à luz noturna e a construção da intimidade. In. OLIVEIRA, A. C. de. (org.). Semiótica plástica. São Paulo: Hacker, 2004, p. 215-227.

FREUD, S. Três ensaios sobre a teoria da sexualidade (1905). In. FREUD, S. Obras Completas. Tradução de Eudoro Augusto Macieira de Souza. Rio de Janeiro: Imago, 2006. v. 7, p. 117-231. (Edição Standard Brasileira)

FREUD, S. O estranho (1919). In. FREUD, S. Obras Completas. Tradução de Eudoro Augusto Macieira de Souza. Rio de Janeiro: Imago, 2006. v. 17, p. 233-273. (Edição Standard Brasileira)

JULLIER, L.; MARIE, M. Lendo as imagens do cinema. São Paulo: Senac São Paulo, 2009.

LOISELEUX, J. La luz en el cine: cómo se ilumina con palavras; cómo se escribe con la luz. Barcelona: Paidós, 2005.

QUINET, A. Um olhar a mais: ver e ser visto na psicanálise. Rio de Janeiro: Jorge Zahar, 2004.

RANK, O. O duplo: um estudo psicanalítico. Porto Alegre: Dublinense, 2013.

SONTAG, S. Sobre fotografia. São Paulo: Companhia das Letras, 2004.

STOICHITA, V. Breve história da sombra. Lisboa: KKYM, 2016.

XAVIER, I. Do texto ao filme: a trama, a cena e a construção do olhar no cinema. In.

PELLEGRINI, T. et al. Literatura, cinema e televisão. São Paulo: Senac; Instituto Itaú Cultural, 2003, p. 61-89. 
ZALCBERG, M. Amor paixão feminina. Rio de Janeiro: Elsevier, 2007.

\section{Referências audiovisuais}

A Erva do Rato. Júlio Bressane, Brasil, 2008.

Artigo recebido em 06/01/2020

e aprovado em 21/04/2020. 